PART THREE

\title{
The Duce, or the Romance of Undemocratic Governing
}





\section{7 \\ Promoting a Romantic Biography}

The public man is born "public"-he bears the stigma from his birth. [...] He can never escape it. [.. .] I am perfectly resigned to my lot as a public man. In fact, I am enthusiastic about it.

MUSSOLINI, $1925^{1}$

The rise of Benito Mussolini on the world stage is conventionally associated with the March on Rome of late October 1922, which forced the Italian king to appoint the Fascist leader to the post of prime minister. The American media coverage of the events was extensive: interest in his striking rise to power, original personality, and leadership pervaded daily reports and editorials. Soon periodicals devoted commentary and illustrations to the iconic Fascist leader, and within a few short years newsreels began to feature him as an alluring celebrity. Economic and geopolitical factors explain the interest that American financial and political centers had in his anti-Communist leadership but do not clarify his status as an iconic public personality, which resulted from a host of public relations efforts informing an intense media coverage.

In truth, Mussolini had already attracted the attention of a very limited but not inconsequential group of individuals years before the March on Rome. After the United States joined the hostilities, American officials found themselves benefitting from this pro-war socialist's remarkable ability of stirring public opinion to accept Italy's participation in the conflict and alliance with the United States. In the late 1910 and early 1920s, he positioned himself as an invaluable anti-Bolshevik interlocutor and a loyal ally to financial centers seeking to invest in a strike-free nation. In this section, I tell the story of how mainstream media support for the Duce consistently intertwined geopolitical rationales and alleged individual traits according to a personalizing strategy that Mussolini himself, a longtime journalist, skillfully exploited. Even though several reporters, editors, and writers of leftist and liberal bents condemned what they recognized as a coup détat, a number of American and Italian mediators enabled his rise to fame by fostering a personality cult that largely deterred any serious questioning of his antidemocratic regime. 
They did so at least until the mid-193os, when his American fortunes shifted for worse following the Duce's decision to emulate other colonial powers and start his imperialistic campaign in Africa.

\section{WARTIME PUBLIC INFORMATION}

As discussed in chapter 1, the Committee for Public Information had branches all over Western Europe, including in Rome. Between April and October 1918, the head of the Italian CPI was the eminent political science professor Charles Edward Merriam, whom many regarded as "the most important political scientist of the interwar years."2 As the American high commissioner for public information in Italy, Merriam's mission was to encourage the Italian public to have faith in the country's military alliance with the United States, support pro-war socialist leaders, and undermine anti-war socialist and communist groups. ${ }^{3}$ Despite his short tenure, Merriam was perhaps one of the truest interpreters of Wilson's propaganda-based diplomacy. In his role, he came into contact with the most important men influencing Italian public opinion. Possibly among them was Mussolini who, after being expelled from the Socialist Party in late 1914 due to his sudden pro-war stance, embraced a rhetoric of militaristic nationalism and broadcast it through his new interventionist newspaper Il Popolo d'Italia. ${ }^{4}$ Diplomatic historian Louis John Nigro Jr. has suggested that it was quite likely that in 1918 Merriam offered financial support to Mussolini's newspaper to increase its circulation and subsidize a Rome edition. Funneled through the Rockefeller Foundation, Merriam's support compensated the future Duce for his influential support of the American war intervention and contributed to his public ascendancy. ${ }^{5}$ This occurred just as the CPI was endeavoring to advertise President Wilson in Italy as the personification of a nonpartisan moral authority and idealistic champion of democracy and world peace. Merriam was in Italy when Mussolini celebrated Wilson's popular authority with a six-column front-page headline in Il Popolo d'Italia that hailed the American president as "the supreme duce of the free peoples" (figure 30). Mussolini would soon adopt for himself the same rhetoric (and lexicon).

Upon his return to the United States in late 1918, Merriam wrote an official account of his Italian experience for the American Political Science Review. It read like a manifesto of realpolitik, pleading for better-funded and -organized propaganda efforts not just to strengthen patriotic idealism but to serve geopolitical interests. "International misunderstandings," Merriam noted, "menace our industrial, political, social and national ideals and progress." The selling of Wilson's America-and with it, American interests-to Italy was premised on the notion that, as he wrote to George Creel in June 1918, "Italy needs the influence of some great international personality."

Merriam did not name anyone in particular, but his close office colleague in Rome, Gino Speranza, used the same argument to identify an Italian, not a 


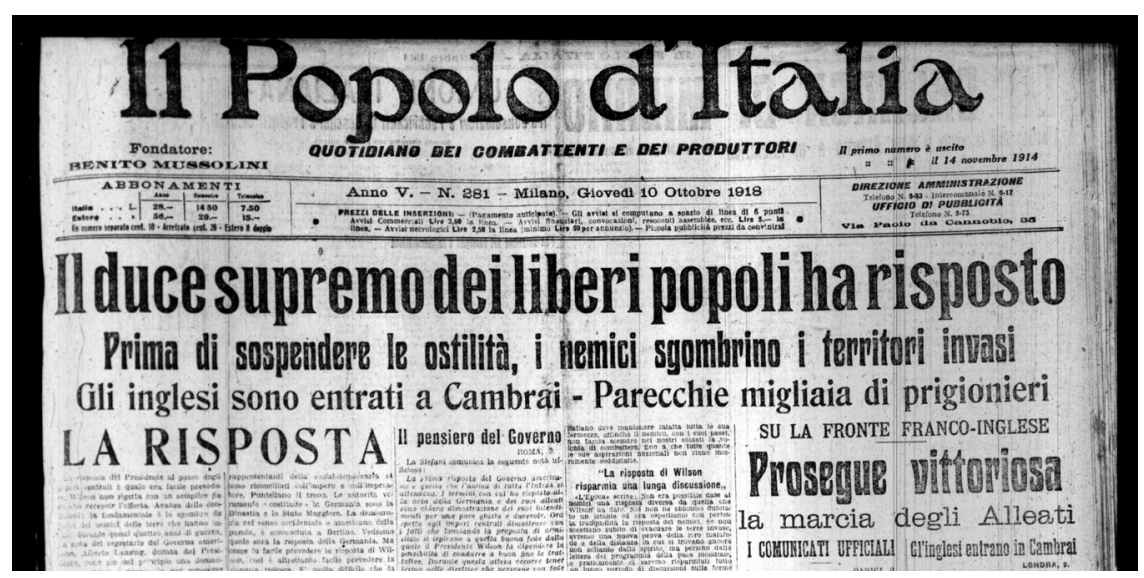

FIGURE 30. Woodrow Wilson headlined as "the supreme duce of the free peoples." Il Popolo d'Italia, October 10, 1918, 1. Courtesy of Biblioteca Nazionale, Rome.

foreign, figure. Speranza was an Italian American lawyer who was serving as personal aide and advisor to the American ambassador to Italy. On July 1918, he reported to Washington about "a man of vision," whom he identified as "the fighting leader of the Reform Socialists," whose popularity was winning approval among "members of all parties." Given his public profile, this person could only have been Mussolini. Against the fear that Italy could have been next after Russia to succumb to a communist revolution, Speranza's reassuring reports provided indications of a possible and very welcome counter-strategy. Beyond the political influence of any "great international personality," what was needed for Italy was the emergence of a strong, anti-Bolshevik Italian leader. This remained the American view for years to come.

After the war, President Wilson experienced a dramatic drop in popularity in Italy because of his intransigence regarding the destiny of the Adriatic city of Fiume. Concomitantly, Mussolini replaced the dogmatic "poet-soldier" Gabriele D'Annunzio, the defeated leader of the occupation of Fiume, as Italy's nationalist icon. ${ }^{9}$ The Duce's early-1920s rise to domestic and international fame was part of a script that unfolded against an ideological landscape of growing misgivings about the stability of Italian democracy and fears of a Bolshevik drift. In this context, Mussolini became of great geopolitical interest to the United States because of his relationship to America's immediate economic and political goals. The novelty of his authoritarian style also mattered to American political scientists and observers because of what it could teach about future governmental arrangements in America. In Merriam's 1931 analysis, Italy represented a "striking experiment," one "full of meaning for the student of civic training."10 It was an experiment that had started at least officially and certainly with great promotional efficacy with the March on Rome, to which I now turn. 


\section{NEWS OF THE MARCH ON ROME}

Almost a century later, the abrupt and dramatic effectiveness of Fascism's power seizure is still compelling, but it also has the whiff of a colorfully choreographed performance that was taken all too seriously. As a combination of a staged threat of insurrection and actual violence between Blackshirts and Communist activists throughout the country during the week of October 22-29, the March on Rome succeeded in forcing the king to give Mussolini the reins of the country. In theory it was a perfectly constitutional and legal power transition. In practice, as several observers recognized, it was a usurpation by an autocrat who had plotted the whole initiative away from Rome. Few expected it to be followed by even more dramatic moves. Twenty-six months later, Mussolini erased the authority of the Parliament and inaugurated a full-fledged dictatorship.

Italy's most politically gifted minds did not necessarily see it coming. Initially, notable anti-Fascists like Gaetano Salvemini deemed Mussolini a "clown [. . . ] surrounded by young thugs," who was bound to "defeat himself." ${ }^{11}$ Eventually, Salvemini explained the march as a "coup d'état, staged as a spontaneous rising of 'Blackshirts', but in reality carried out by a military 'Black Hand." "12 While the confrontations between the Fascist militia and socialist groups resulted in dozens of deaths and hundreds of injuries, the human cost of the march went largely unreported. Journalists regularly insisted that there had been virtually no clashes between the police or the army on the one side and Mussolini's Blackshirts on the other. For instance, on October 31, 1922, the St. Paul Pioneer Press described the March as a coup détat "accomplished with extraordinary skill," and a few months later the Wall Street Journal was still praising Mussolini for taking "Italy without shedding a drop of blood." "13 To outsiders, the march was a coup d'état sans coup. Several commentators read this as a sign of widespread consensus. Others diagnosed it in a bleaker fashion, as an undemocratic abuse of power resulting in unreported violent acts.

Over the decades, historians of Italian fascism have studied the March on Rome by seeking to move past reductive and ritualistic celebrations or condemnations. Despite marked methodological differences, they have shared the view that the name March on Rome is misleading on multiple levels because it refers to a single event unfolding in a single geographic site. ${ }^{14}$ What they have agreed upon is that the atmosphere of confusion and the collapse of state power led to the choreographically effective Roman scene as the watershed moment for Mussolini's political stature.

Though it has enlarged its focus from the city of Rome to an Italian theater, mainstream scholarship on the early days of the Fascist government has largely operated within an intranational framework. The context and theater of the March on Rome consisted of a broader, international scene that prominently featured the geographically distant United States. ${ }^{15}$ The mediating role of American journalists and, especially, governmental officials reveals that they quickly recognized the 
importance of the events of late October 1922, before, during, and immediately after their unfolding: America's key political and financial players were not passive spectators of Mussolini's rise to power. While they did not aid Mussolini's ascendancy in situ, they fostered American public opinion's positive reaction to, and thus legitimatization of, his quick seizure of power.

Despite a few cautious responses (and fewer denunciations) to the Blackshirts' violent methods, several first responses to the march were celebratory, in fact. It was not just that notable individuals and organizations that expressed high expectations for Mussolini's appointment as Italian leader. What was remarkable was the swiftness with which the American press published positive responses to the Duce, within days or just a few weeks of his ascent to power. The tempting explanation for this rapid approval is that Mussolini met American aspirations for a leader who could not only counter the strikes and disorder that was disrupting the country's political and economic life, but who could do so with wide popular support. The lack of substantial reports about the human costs of the March on Rome provided the much-desired proof of Mussolini's popularity. Still, more precise questions ought to be asked. Where did these papers get their news?

Beyond the power interests at stake in the published stories, of notable historical importance was the infrastructure of the coverage-that is, the network of journalists working for wire services and major newspapers. In the early 1920 , 120 members of the foreign press worked in Rome, and "of these, perhaps 40 to 50 were genuine correspondents, the rest were police spies or hacks in the pay of the regime." Most American newspapers received their foreign dispatches from the few Rome-based news bureaus (i.e., Associated Press, United Press, and International News Service), which were largely friendly to the regime. ${ }^{16}$ There were also newspapers that could afford direct reports from Italy, including the New York Times and the Christian Science Monitor, as well as the Chicago Daily News and the Chicago Tribune. They too, with notable exceptions, were not inimical to the regime. The New York Times counted on several correspondents who generally tended to report favorably or with measured distance on Mussolini, as did the Christian Science Monitor. The coverage from Chicago was polarized. For most of the initial Fascist period, the Chicago Daily News correspondent was the Fascist sympathizer Hiram K. Motherwell, who in 1928 would even translate Mussolini's 1908 novel, The Cardinal's Mistress. ${ }^{17}$ The Tribune's George Seldes, instead, wrote such extremely critical articles about the regime that they eventually cost him his job. ${ }^{18}$ Another fierce critic was the South African British writer William Bolitho, who wrote for both Walter Lippmann's World and the Manchester Guardian. His 1926 volume Italy under Mussolini called Mussolini's rule "tyranny" and labeled it a "slave state."19 Other outlets debated whether Fascism truly represented the will of the Italian masses or whether Mussolini was just the leader of a violent mob.

The coverage of the events in Rome did not always focus on Mussolini. A few isolated articles focused more on Fascism as a novel ideology and a mode of governance. 
In early October 1922, Current Opinion described the Fascist movement as fundamentally a "challenge," not aristocratic but highly popular, to the weakness of traditional governments. ${ }^{20}$ The New Republic included articles by journalist and writer Giuseppe Prezzolini, an old friend of the Duce. In November 1922 he praised Fascism as an "utterly new movement" that "had become particularly 'popular." "21 The same month, the former military attaché of the U.S. embassy in Italy, Gino Speranza, argued that, despite its violence, the Fascist movement was the revolt of the middle class against the "sinister spell of an exotic Marxism." ${ }^{22}$ A few months later, he described Fascism in Outlook as a "spiritual national reconstruction." ${ }^{23}$ In a few rare instances, publications that primarily focused on the Blackshirts took a more worried stance due to these Fascist adherents' overt use of violence. Newspapers and periodicals like the New York Tribune and Literary Digest published dystopian descriptions and cartoons that painted the Blackshirts as a backward and violent movement, comparable and related to America's Ku Klux Klan (figure 31). Other outlets instead openly defended the authoritarian modus operandi of the Blackshirts, arguing that their youthful antidemocratic force was the right medicine for Italian democracy's sick and aging body. They appeared to rehash the forgiving rhetoric that in 1921, Anne O'Hare McCormick, then a young freelance contributor to the Book Review and Magazine of the New York Times, had deployed when covering the Fascists' violence in Rome. Through her romantic view of Italy as a land of artworks, she hailed the socialists' riotous protests and staining walls of medieval churches with Soviet slogans as the very epitome of brazen disorder and demagogic tyranny. Fascism, instead, was for her the middle class's "healthy and necessary reaction," perhaps "a ruthless movement, as youth is ruthless," but capable of substituting "swift and decisive action for the slow processes of legislation and experiment." ${ }^{24}$

By and large, however, Fascism and the Blackshirts were intertwined with the figure of the Duce and consequently deserving positive consideration as a worthy political movement and method. Just a few days after the March on Rome, the New York Tribune described Mussolini as “A Black-Shirted Garibaldi," referring to the celebrated military commander that led the 1860-1861 state formation. With Mussolini, the paper continued, Fascism was "rough in its methods," but it had "tonic" aims "against degeneration through Socialist internationalism." Ultimately, if "Garibaldi won freedom in a red shirt, Mussolini is fighting for normalcy and Italianism in a black one." ${ }^{25}$ The New York Times intertwined its description of Mussolini as a de facto "dictator of Italy" with a celebration of the Fascist revolution as a "relatively harmless Italian type" of political upheaval. ${ }^{26}$ On November 3 , the New York Herald praised the forty-year-old Mussolini as the "regenerator of the Italian nation." ${ }^{27}$ It was a flattering compliment, though one still within the domain of conventional political rhetoric. On the same day, however, the Birmingham AgeHerald wrote that Mussolini looked "like a movie star," which was clearly a move away from traditional political assessments and even from the most enthusiastic forms of praise. ${ }^{28}$ Instead, this comparison signaled unprecedented attention to 


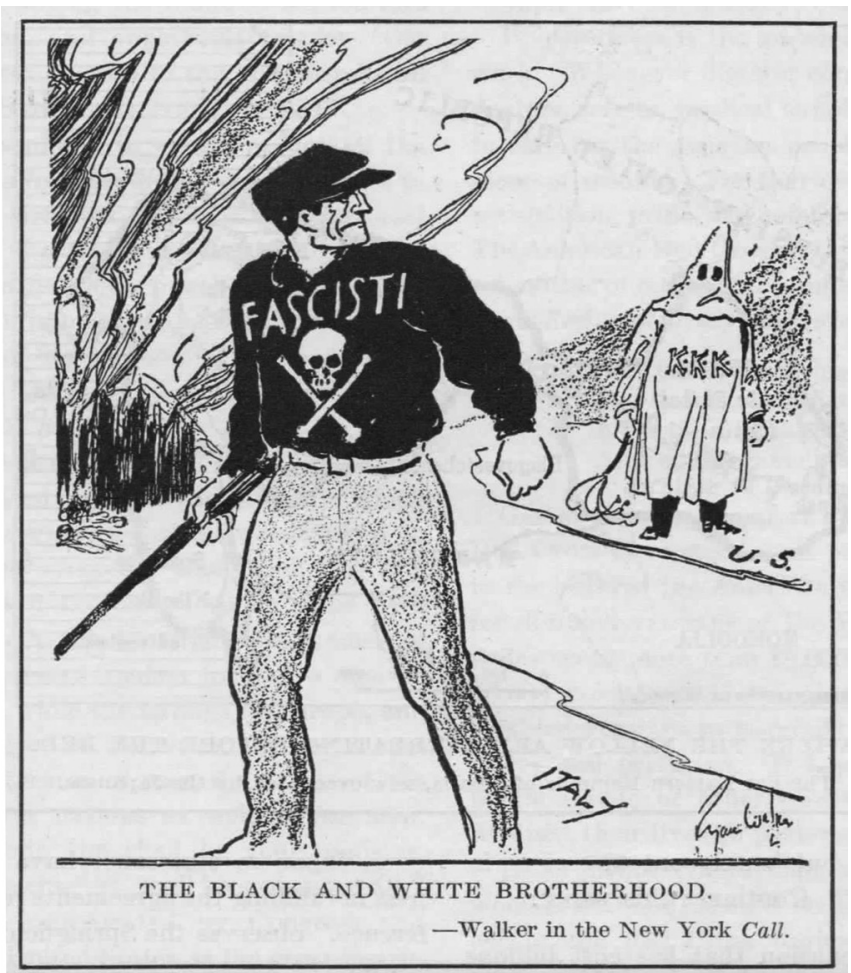

FIGURE 31. The Blackshirts compared to the KKK. Literary Digest,

November 11, 1922, 13 .

and celebration of a new, personalizing set of characteristics for a contemporary leader: political power, physical presence, and personal appeal. As other similar comments reveal, the Duce's masculinity exuded an old-fashioned charm, but it also expressed the irrepressible energy of modern youth.

As the newly appointed New York Times Rome correspondent, McCormick contributed to a view of Fascism as a governmental style that matched its histrionic and hypermasculine leader. She celebrated the new premier as "swashbuckling Mussolini," using a term usually applied to Fairbanks. ${ }^{29}$ McCormick repeatedly deployed a pragmatic rhetoric and medical metaphors in defense of Mussolini's antidemocratic methods. Assuming "one-man power to be less dangerous than the powerlessness of many men," she wondered whether he was not the remedy to "the disease of politics that infects civilization." Most interestingly, she argued that Mussolini's autocratic methods were justified by his popularity. "The people were already yearning for a dictatorship when Mussolini appointed himself a dictator," she charged. "His march on Rome was like an answer to a prayer."30 What fueled his popularity was not necessarily an ideology, about which McCormick never had 
much to say, but governance through the crowd-pleasing showmanship that dominated the press coverage at home and abroad. Nobody had ever seen anything like it in Italy before-or elsewhere, for that matter. "The new government cultivates the spectacular," she observed before claiming that "one of the reasons for its popularity among a people" that was usually undervalued was that Mussolini gave "them at last a leader who is a headliner, so to speak, able to command public attention and keep Italy on the front page." More than a politician, he was a celebrity, even though McCormick never used this term: "He makes politics a kind of noble show and keeps enlivened and interested the audience, so bored by his predecessors." ${ }^{31}$

As a political celebrity, Mussolini could be compared to non-Italian political superstars, which heralded the recognition of a fame that stretched beyond the limited domain of politics-as he well knew. In mid-1923, in the pages of the New York Times Book Review and Magazine, McCormick compared Mussolini to Theodore Roosevelt: "A nation that thrilled to the Vigilantes and Rough Riders rises to Mussolini and his Black Shirt Army." ${ }^{2}$ By 1923, books in English about Fascism and Mussolini were regularly featured on the shelves of American bookstores, sold as comparable to the celebratory profiles of American business and political heroes. This literature was often characterized by a description of Mussolini's authoritarian stewardship as a reaction to inanity and incompetence, with some reservations about his use of violence. ${ }^{33}$

His leadership and popular consensus thrilled the business community, which had been discontented with the feebleness of postwar Italian governments. Writing in the pages of the Nation's Business, Basil Miles, the Paris-based American representative of the International Chamber of Commerce, praised "Mussolini's Blackshirts as a potent factor for better business" and deemed their actions a "bloodless revolution against a wasteful government." Miles's article included a detailed account of Mussolini's economic program, based on the "abolition of the law compelling the registration of all securities," which had discouraged investors and delayed the "flow of capital into industry." The program also included radical tax reform, privatization of telephone services and railways, reduction of state expenses, and balancing the national budget. ${ }^{34}$ Unsurprisingly, the U.S. business press (i.e., Barron's Commerce and Finance, the Nation's Business, and the Wall Street Journal) was overall quite optimistic about Italy's economic prospects under Mussolini. ${ }^{35}$

Praise of the Duce's undemocratic authority often impinged upon a misogynist rhetoric. As a self-made patriarch, the son of a blacksmith, and someone tirelessly engaged in continuous self-improvement, Mussolini was the virile new leader domesticating a stereotypically unruly nation gendered as feminine. In 1923, Time magazine put him on its cover for the first time with a caption that referred to castor oil, which Fascists forced their opponents to drink and which became, together with the bludgeon, a symbol of Fascist discipline and obedience. A few years later, another Time magazine cover showed him courageously behind bars with a lioness that he had tamed. Her name was Italia. ${ }^{36}$ 
Even critical reports, such as those that often appeared in Literary Digest, referred to and popularized Mussolini's Caesarism, especially when granting him space in direct or indirect quotes from interviews. The Duce's political novelty, in fact, came with an outspoken rejection of democracy ("mass cannot govern mass") and liberty ("civilization is the inversion of personal liberty"). ${ }^{37}$ The same articles also popularized his direct, acclamatory definition of Fascism as the change "from parliamentary government [...] to a government in which the prime minister is directly bound to the multitude." ${ }^{38}$ Emboldened by the space granted to it in the press, Mussolini used his celebrity status to justify his regime's methods. When rumors spread regarding fascism's antidemocratic policies, the Saturday Evening Post adopted medical metaphors to argue that "desperate diseases need desperate remedies. Italy was a surgical case that called for a major operation." ${ }^{39}$ In her 1924 overview of world's dictators, McCormick praised Fascism as "the triumphant example of popular and successful dictatorship" and found the Duce's style of plebiscitarian governance ("Mussolini glories in autocracy") utterly acceptable and even better than the American system. "The people may not be freer than they were under a weaker and more representative government, but they are certainly freer from trouble," she opined. She went on to claim that "under Mussolini [Italy] has changed from an enfeebled and divided kingdom into one of the most [...] prospering powers of Europe," where Italians enjoy "a personal liberty unknown in an indefatigably regulated commonwealth like ours." ${ }^{\circ}$

In the early years after taking power, Mussolini sought to exercise a measure of control over the promotion of his leadership. While keen on nurturing personal relationships, he soon benefitted from more institutional forms of publicity mediation that would articulate and sustain his positive reception in America for years, through the near fatal delegitimization of his regime in the aftermath of the 1924 Fascist murder of Socialist congressman Giacomo Matteotti. ${ }^{41}$ Mussolini's assumption of personal responsibility in a January 3,1925 , speech to the Parliament is often regarded as the official beginning of Mussolini's dictatorship. Before, during, and after the Matteotti crisis, Mussolini, as both prime minister and minister of foreign affairs, relied on a network of mediators, consisting of the entire Italian diplomatic corps in the United States, beginning with the embassy and the consul general of New York. The diplomatic force made a critical alliance with the Italy America Society (IAS), a key lobbying association with links to the State Department and Wall Street, as well as to powerful individuals such as U.S. ambassador William Washburn Child and the chief executive at J. P. Morgan \& Co., banker-diplomat Thomas W. Lamont. Often advised by IAS's president, corporate lawyer Paul Cravath (who had ties to J. P. Morgan), the Italian embassy put American journalists and editors in direct contact with Mussolini. Through a system of patronage that guaranteed access and sumptuous receptions in Italy, the Duce befriended a whole host of journalists and writers, including Isaac F. Marcosson of the Saturday Evening Post; public relations experts and periodical contributors, including Ivy Lee; 
and bankers and businessmen, including John Morron, a director of the First National Bank of New York, and financier Charles Torrey. These relationships proved quite effective. Even when periodicals sought to publish critical reportsas, for instance, the Atlantic Monthly, Harper's Magazine, and Literary Digest didtheir coverage still amounted to publicity. It is to these most formidable mediators that we shall now turn.

\section{A CLOSED SOCIETY: THE JOURNALIST, THE BANKER, THE AMBASSADOR}

Dear Dad, we are having a fine revolution here. No danger. Plenty of enthusiasm and color. We all enjoy it.

RICHARD WASHBURN CHILD, U.S. AMBASSADOR TO ITALY, TO HIS FATHER, THE DAY AFTER THE MARCH ON ROME ${ }^{42}$

The most reliable network of publicity mediators that Mussolini depended on for his swift and favorable emergence in American public opinion was the Italy American Society (IAS). Since its establishment in March 1918, IAS had the goal of fostering "between the United States and Italy an international friendship based upon mutual understanding of their national ideals," which essentially meant, as the masthead of its News Bulletin boasted, a "co-operative effort to develop international trade." 43 To accomplish this, IAS intertwined the interests of both the State Department and Wall Street on the American side with those of the Italian embassy on the Italian side.

With some pretense of cultural engagement with a nation that was rich in art but poor in infrastructure and foreign investments, IAS sought to open up a political space for new financial and economic relations between the two countries. Although nominally private, the IAS relied on a broad network of powerful interests: the American and Italian American financial community, the Italian and U.S. governments, and Italian American leaders. ${ }^{44}$ Through the press influence of these interests in the two countries, IAS contributed-directly and indirectly-to manage Mussolini's reputation within the broader U.S. financial, governmental, and popular spheres. ${ }^{45}$

On the economic side, IAS's reach was ambitious. Like the bankers and corporate lawyers who constituted its membership, the most prominent of whom were linked to J. P. Morgan \& Co., IAS was favorably disposed toward Italy, whoever its leader, even before the March on Rome. ${ }^{46}$ Morgan's "purchasing organization had executed large orders on behalf of the Italian military during the war" and, after the end of the conflict, sought to do "a substantial underwriting business in Italian securities." 47 In many respects, IAS considered Mussolini just the next leader, the one it had to deal with after the failure of the previous liberal governments. In other respects, Mussolini was such a peculiar politician that arguments for promoting investments in Italy could not be merely economic. In this regard, 
IAS provided a highly placed public relations platform for Mussolini's political legitimacy, which was a key condition for American investments in Italy. A quick rebuttal against the argument that his government was autocratic-a word that the war propaganda had taught Americans to condemn-was a priority. In its first Trade Bulletin (October 1922), published after the March on Rome, Irene di Robilant, an Italian aristocrat living in New York who was to become IAS's organizing factotum, quenched any anxiety about the Blackshirts' quick and seemingly authoritarian rise to power. In a three-page editorial, she described the Fascisti as the heirs of Garibaldi's Red Shirts and "the power and the law of ancient Rome" and referred to Mussolini as a genius organizer who "personifies their power in action." 48

On the political side, the IAS's reach was equally impressive. Reproducing Wall Street's financial giants' intertwined approach to finance and world politics, IAS cultivated powerful ties with many parts of the U.S. government, particularly the State Department. In the spring of 1920, Thomas Nelson Page, who had been ambassador to Italy from 1913 to mid-1919, was elected an honorary vice president of IAS. ${ }^{49}$ The same annual elections appointed a forty-year-old Harvard-educated lawyer, writer, journalist named Richard Washburn Child to the IAS executive committee..$^{\circ}$ A year later President Harding nominated him U.S. ambassador to Italy (figure 32). Child represents one of the most interesting contributors to the convergence of political and cultural characterization that informed Mussolini's public image.

Unlike Page, whose clashes with Merriam revealed his opposition to overt propaganda tactics, Child had no diplomatic background. ${ }^{51}$ Instead, in the 1910 s while working in a New York law office, he had started his public career as a writer, publishing short stories and a few novels..$^{52}$ A lifelong Roosevelt supporter, he had also written a few influential political pieces for Century Magazine and McClure's Magazine that consistently stressed vigorous citizenry and strong leadership. ${ }^{53}$ His horizons widened when, before the U.S. involvement in the European war, he took up assignments first as a foreign correspondent in Europe and Russia and then as a publicity man for the U.S. Treasury. In 1916 he published Potential Russia, a book that called for U.S. investments in the tsarist nation. ${ }^{54}$ The Soviet Revolution scrapped any such plan. Still, known as a writer conversant in foreign affairs and a policy promoter, he worked during the war for the CPI's Division of Features, "which enlisted the volunteer services of the leading novelists, essayists and short-story writers of America." ${ }_{55}$ Writing in 1919 about Wilson's centralization of war powers, he justified the president's "one-man leadership" as "the only emergency action we know" despite his long-standing opposition to the former New Jersey governor. ${ }^{56}$ At war's end, Child worked briefly as the editor of Collier's Weekly, covered the Paris Peace Conference, and attacked Wilson's League of Nations for what he feared was America's unnecessary involvement with foreign nations. He promoted a Progressive social politics and a pragmatic isolationism that supported economic interests with minimum political involvement. He continued to denounce the demise of representative democracy 


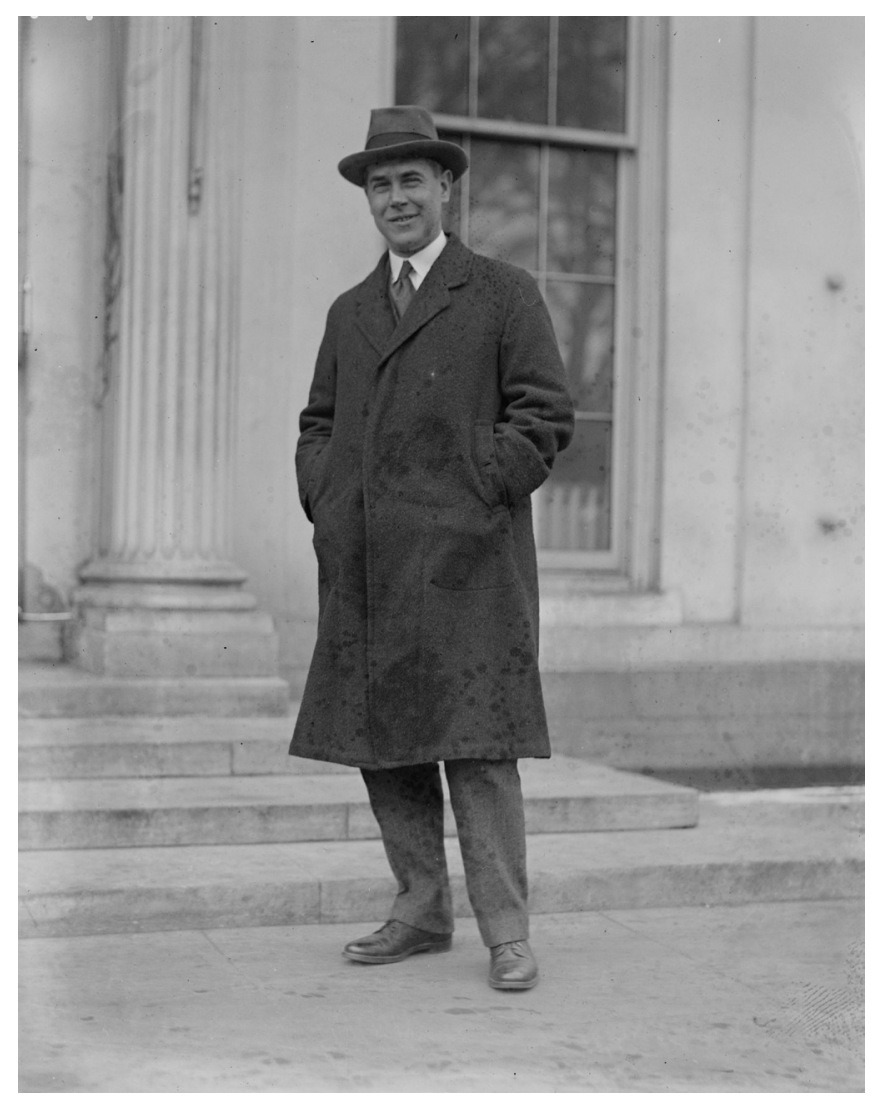

FIGURE 32. Richard Washburn Child in Washington, DC, 1924.

Photograph (digital file from original). Library of Congress, Prints \& Photographs Division, LC-DIG-npcc-10526.

and leadership that perniciously advantaged financial and industrial elites. In 1920, possibly thanks to his connections among the New York City's lawyers, he joined IAS's executive committee, which, as Child had viewed Russia in 1916, looked at postwar Italy as a favorable investment destination..$^{57}$ In the same year, he wrote effective speeches for Warren G. Harding, contributing to his election. On May 26, 1921, the president awarded Child the ambassadorship to Italy. Child probably did not know the first thing about being a diplomat. Rather than limiting his role, however, his background in creative writing and political advocacy was going to provide the skills he needed to promote Mussolini in America. The New York Times reported that Child was "the first of the 'younger generation' of American writers to achieve ambassadorial distinction." ${ }^{8}$

During Child's first months in Rome, the context of the relationship between the United States and Italy was dominated by two intertwining elements: the threat 
of Bolshevism and the question of war reparations. Italy had experienced two years of massive disorder and strikes that had revealed the government's inability to control the violent clashes between Socialist forces and a rising Fascist militia, and, in the process, weakened the national economy. The U.S. government's fears about the instability of the Italian administration, subject to continuous reshuffling and changes of coalitions, prevented any long-term American political and economic commitment. ${ }^{59}$ The American embassy and consulates in Italy kept the State Department well-informed on the country's climate of violence and instability. ${ }^{60}$ For instance, Child informed Secretary of State Charles Evans Hughes that Mussolini was emerging as a leader firmly in control of the most violent elements of the Fascist political movement. In early October, Child apprised Hughes that Mussolini was willing to start a revolution and become Italy's dictator. "People like the Italians hunger for strong leadership," he wrote, seemingly with approval, "and enjoy [...] being dramatically governed." ${ }^{11}$

Child's communications were not merely the result of an impersonal political assessment. Apparently Mussolini, who had a profound appreciation for America's political support, had befriended him. A few days before the March on Rome, in fact, the Duce visited the American embassy and informed Child of his plan! The ambassador immediately notified Hughes. "A few days ago," Child wrote on October 26, "Mussolini came to see me and addressed to me inquiries as to the attitude of the American public toward Fascisti." ${ }^{2}$ There is no record of Hughes's answer, but it is not difficult to guess what it was. Given Child's previous cables and given any lack of an agitated response from the State Department, the response must have been cautious but positive. ${ }^{63}$ Even with the intense domestic negotiations about Mussolini's seizure of power, he apparently remained quite attuned to the American response. A few hours after being nominated prime minister, one of his first public acts was to cable Secretary of State Charles Evans Hughes cordial good wishes and "express confidence in the friendly, economic and spiritual collaboration of our two countries." ${ }^{64}$ Hughes duly responded shortly afterward, congratulating Mussolini on his new position and assuring him that the collaboration between Italy and the United States would continue to promote their mutual interests. $^{65}$

Mussolini went out of his way to show that his relationship with American officials was quite special and unique. In early November, Child approached the premier's office to ask for the customary meeting with the new head of government. The opposite happened. Child made this report to the State Department:

In response to my request to be received by the new minister [...] Mussolini instead of making an appointment called upon me this morning for an extended interview explaining his departure from the usual custom on the basis of personal friendship and his desire to emphasize his belief that while Italy should maintain friendly relations with all nations, an understanding of the new Italy and its young and 
progressive spirit by the American government and particularly by the American people was of primary importance. He said that American cooperation was vital for the plans he had in mind. ${ }^{66}$

What Mussolini had in mind was the opening up, through the State Department, of special channels of communication with the business and financial world and, in turn, with American public opinion. The terrain of such possible future economic cooperation - and the bait-was economic progress, which all parties understood to be vital for reparations payments. This promoted policy amounted to privatizing public utilities, especially railways, and opening them up to U.S. investments. "Americans would be given all the opportunities this policy might yield," Child reported Mussolini telling him. As for the public image of Fascism, Mussolini insisted on a politics of alliance between capital and labor, as opposed to the "false hopes and vaporous expectations" that had been instilled previously by the Socialists upon the population. ${ }^{67}$ Child registered all these arguments and ended his communication in formal diplomatic terms: "Mussolini indicates that he would appreciate it if the Department were to inform the American press that he had made to me 'hearty expression of friendship for America and of faith in mutual frankness in all exchange of views [between] the two nations." Finally, he summarized Mussolini's plan: "In brief, I believe he hopes that the Department will find a way to give him a little American publicity." ${ }^{68}$ Child would take Mussolini's request to heart.

For the American government, the dramatic, but apparently orderly regime change in Italy was good news: there would not be any further risk of a Bolshevik revolution in Italy and reparations repayments would have been made on a regular basis. Still, from the American perspective, how could the country that had justified its war participation as a battle of democracy against autocracy now go on supporting Mussolini's authoritarian and overtly antidemocratic regime? The best way Washington and, with it, Wall Street could justify support of Fascism to American public opinion was by broadcasting the new Italian regime's unwavering commitment to a capitalist economy and openness to foreign investments. Such important preconditions, however, could not sufficiently build Mussolini's celebrity status in the United States. His full American acceptance depended on narratives that could script his personal and political biography in more relatable ways. What diplomatic communications, press briefings, and newspaper editorials seemed to share was a focus on his widespread attractiveness and recognition-at home and abroad. In his dispatches from Rome, Child was quick to characterize Mussolini as widely popular and uniquely capable of bringing the country to normalcy. And, in the post-Wilson era, normalcy was the precondition for international alliances. ${ }^{69}$ Against "weak and halting ministers, who for four years have been unable to lead," Child wrote, "Italians prefer a determined Mussolini," who has a "magnetic character" and a "stern deportment and convincing oratory." 
In these colorful descriptions, Child-the-diplomat was handing the baton to Child-the-fiction-writer, a practice he was keen on repeating.

A little more than a year after the March on Rome, for instance, Child was the guest of honor at an IAS dinner held in New York on November 27, 1923. Child's speech had nothing of diplomatic reportage. Instead, it combined political advocacy (or partisanship) with a heavily personalized rhetoric that, to the ears of the businessmen in the room, helped legitimize investment opportunities in Italy. Child spoke about Italy and U.S. foreign policy and announced the dawning of a new political season, not solely for Italy but for America and world politics in general. The rhetorical impetus for his argument centered on the figure of the Duce:

The tide has turned. The word democracy attached to drifting mobs no longer deceives us. We have come back to the realization that often the great hunger in the human heart is for strong leadership. We have come back to a decent appreciation that no matter how much we may desire to pat the heads of the weak and the wailing, no matter how great our pity and our charity, the hands worthy of our clasp of friendship are the strong and honest hands. ${ }^{71}$

In other writings and public speeches, while holding office and afterward, Child consistently articulated the same narrative about Mussolini, one centered on his daring and iconic leadership vis-à-vis the lack of efficacy of democratic governments. $^{72}$

In assessing Child's effectiveness as a public relations operative, or as "Mussolini's mouthpiece in America," it is important to recognize the long-standing role of banker-ambassador Thomas W. Lamont, J. P. Morgan's exceptionally gifted and influential executive. During and after World War I, J. P. Morgan \& Co. had already played a key role in financing the Italian military effort and postwar reconstruction. After the March on Rome, the American firm led by Lamont was ready to endorse Mussolini as Italy's preferred banking agent for all international financial institutions interested in investing in the peninsula. ${ }^{73}$ Further, the Morgan firm eventually turned out to be the regime's U.S. bank, capable of extending loans to Mussolini's regime. ${ }^{74}$ The banking giant was a fairly constant presence in Child's Italian affairs, having been for a while a close observer of the nation's financial health. ${ }^{75}$ If Child was an activist and perhaps heterodox ambassador, so too was Lamont.

Lamont's active relationship with European affairs started after the end of World War I. Invited by Wilson to attend the 1919 Paris Peace Conference, Lamont was aptly named the "Ambassador from Wall Street" due to his ability to intertwine Morgan's financial plans with U.S. policy. An inveterate Italophile, he was interested in extending his financial skills to a nation he viewed as uniquely "touched with poetry and romance." ${ }^{76}$ To this end, in Paris Lamont networked heavily with members of the Italian delegation. In particular, he befriended Giovanni Fummi, a former stockbroker who was to become Morgan's Rome agent and enable Lamont 
to enter Italy's top financial and political circles. Back in New York, Lamont's involvement with IAS, first as a trustee and treasurer (and in 1925 as president), was widely advertised and often reported in the press. After the March on Rome, Lamont kept up a close relationship with the Italian ambassador Gelasio Caetani by often reporting on criticisms of and negative rumors about Mussolini. At times, he even sought advice on how best to respond to criticism against the Duce. ${ }^{77}$ Six months after the premier had taken office, Lamont met Mussolini to discuss restoring Italy's financial credit, and their relationship would only strengthen in both direct and indirect ways over the next few years. ${ }^{78}$ In the summer of 1924, in the critical aftermath of the Fascist murder of Congressman Giacomo Matteotti, Lamont's reaction was steadfast. He managed to organize a lunch with the editors of all the major New York papers in order to give Ambassador Caetani a platform "for explaining his version of events to the editors and commentators."79

In post-World War I America, references to international leaders were becoming more common to newspaper readers than ever before. Fascism could be sold to Americans, but it all depended on how it was presented. The regime's violent nature had to be masked through national and racial distancing-that is, by stressing that different countries had different political cultures. One of the most direct examples of this rhetoric appears in a letter sent by Lamont to J. P. Morgan's Rome agent, Fummi. The context was the very delicate one of late 1925. Lamont was "considering a loan request for $\$ 100$ million" from Italy, but knew that Secretary of State Frank Kellogg would have vetoed it unless the question of Italy's \$2-billion debt was settled.$^{80}$ Lamont played the role of the skillful mediator. It helped that earlier that year, he had been elected, by unanimous vote, IAS president. ${ }^{81}$ Champion of a style of "relationship banking" in which banker-client rapport went beyond shared financial interests, Lamont, through his Roman representative, offered remarkable advice to Mussolini on how to market his regime in America:

If Mr. Mussolini declares that parliamentary government is at an end in Italy, such a declaration comes as a shock to Anglo-Saxons. If, on the contrary, Mr. Mussolini had explained that the old forms of parliamentary government in Italy had proved futile and had led to inefficient government and chaos, therefore they had to be temporarily suspended and generally reformed, then Anglo-Saxons would understand. ${ }^{82}$

The Morgan executive was relying on a familiar argument. Carleton Beals had written in Current History a few months earlier that historically, Italy was much more familiar with forms of "enlightened despotism," insisting that "the cloak of popular democracy and representative government does not fit comfortably or gracefully upon the body politic." ${ }_{3}$ In the end, Lamont was successful both in advancing the negotiations over Italy's war debt with the United States and securing the loan to the regime. These successes "proved to be a catalyst for further American investment." ${ }^{84}$ Lamont's mediating lesson went on to be applied to other public contexts. It would, for instance, find a profitable application in the unexpected collaboration 
and personal amity between Mussolini and William Randolph Hearst, whose syndicated newspapers and newsreel services would feature the Duce's weekly columns and speeches from October 1927 to May 1935. Overall, Lamont's reputation never suffered from his closeness to Mussolini. In the days after the crash of 1929, he even earned the cover of Time magazine as the "right hand of John Pierpont Morgan [. . . ] who steered the ship of U.S. prosperity through the storm.".85

Another prominent financial operator like Lamont who helped legitimize Mussolini in America and was also a member of the IAS executive committee was the aforementioned banker Otto Kahn. In the mid-1920s, Kahn publicly endorsed Mussolini as a reliable business partner and a guarantor of public order. His eloquent speeches were widely appreciated in the city's financial world and, at times, were even published. One in particular stood out. Kahn gave it to the Foreign Policy Association on January 3, 1926, at the Hotel Astor in New York. The Italian American Fascist periodical Il Carroccio published it in Italian as "Otto Kahn e il Fascismo." In the speech, Kahn defended Italians' political self-determination, but he also argued that in contexts other than the American, democracy and freedom were not necessarily overlapping notions, particularly when the popularity of a leader could productively disentangle them. It is worth reporting the speech's critical passages:

To judge Fascism with fairness we must remember two things. Italy belongs to the Italians, not to the British or the Americans. [...] Secondly, and this is true for every nation, before freedom [...] is the public order and the protection of the idea and life of the nation. True freedom is impossible where there is no order and where a government does not work properly. [...] [Mussolini] is not a dictator in the usual meaning of the word, because he exercises his power with the explicit and overwhelming consensus of the people and by will of the King, the State's constitutional ruler. $^{86}$

Lamont, Kahn, and the New York press could support a favorable reception for Mussolini, but what they all needed was a direct contact with the premier. Such contact was guaranteed by the very gifted Italian ambassador to the United States, Gelasio Caetani (figure 33). For about four years, between 1922 and 1925, and in collaboration with the Italian consuls in America, Caetani mediated between the Duce and American power centers by maintaining direct, personal relationships with Lamont, the U.S. State Department, the Italy American Society, and even Will H. Hays, the chairman of the Motion Picture Association of America. Of noble background, Caetani was a war hero and fervent nationalist. He had taken part in the March on Rome, at the end of which, in November 1922, he was named Italian ambassador to the United States directly by Mussolini. Personally and ideologically loyal to the Duce, he was also right for the job: a prince, a decorated officer, and an engineer trained in Italy and the United States, Caetani was already familiar with American cultural and economic life, and he had a mediating temperament. ${ }^{87}$ 
Celebrated by the New York Times at the time of his nomination, Caetani exuded the charm of old and new Italy. ${ }^{88}$ In early 1923, IAS organized a banquet in his honor as the newly appointed Italian ambassador. The event, which was also under Morgan's patronage, put him in contact with the city and the country's political and financial elite. ${ }^{89}$ In his address, Caetani defended Mussolini's authoritarian actions as both urgent and audacious. "It is not a dictatorial government," he insisted, "but one of unflinching determination to put through those reforms that everybody had been advocating for years but nobody so far had had the courage of applying for fear of unpopularity."90

Even though the embassy had already engaged in publicity initiatives before Mussolini took power, under Caetani's leadership it came to operate like a public relations agency for the Duce. In early November 1922, just a few days after the March on Rome, the ambassador solicited press clippings about the Duce or Fascism from all consular authorities, made summaries, and sent them to the Duce. In one of these cables, the embassy clarified its institutional role: to shed light on the aspects of recent events that Americans might have found otherwise confusing. The government change, for instance, deserved to be explained as resulting from constitutional rules and as being "nothing other than the effect of Italian popular will." ${ }^{11}$ As we saw earlier, this was a message that effectively informed much of the coverage of the March on Rome.

In his dual role as prime minister and minister of foreign affairs, Mussolini used Caetani to relay and publicize his new Italian policies through the "diplomatic, political, financial, and journalistic circles," as Mussolini's short cables insisted. ${ }^{22}$ Caetani's ability to get things done was impressive, whether it meant promoting a new institutional accord between the Fascist Government and the unions (August 1923); ${ }^{93}$ or arranging for a personal meeting between Mussolini and Ivy Lee following Lee's Time Magazine article appreciative of Mussolini's communicative style. ${ }^{94}$ Caetani also introduced Isaac Frederick Marcosson, the European correspondent of the Saturday Evening Post, to the Duce: the relationship with the most important U.S. periodical was to last more than a decade. ${ }^{95}$ Caetani seems to have known or met everybody in Washington, New York, and even Rome. It was in Rome in mid-1923 that he met with Ambassador Child..${ }^{96}$ Caetani was there overseeing the production of a film featuring Mussolini that he had promoted, as we shall see in the next chapter.

Officially, the embassy's political agenda had to address two main questions: the negotiations of the war debt between Italy and the United States, for which favorable economic news about Italy was always helpful, and the dangerous issue of the American Fascists' loyalty to Italy. Their activism was an issue for Rome because their unrestrained violence represented a dangerous form of interference in American affairs and affected the American reputation of Fascism in general.97 Despite the importance of these political matters, a significant portion of the communications between the embassy and consuls related to Mussolini's reputation 


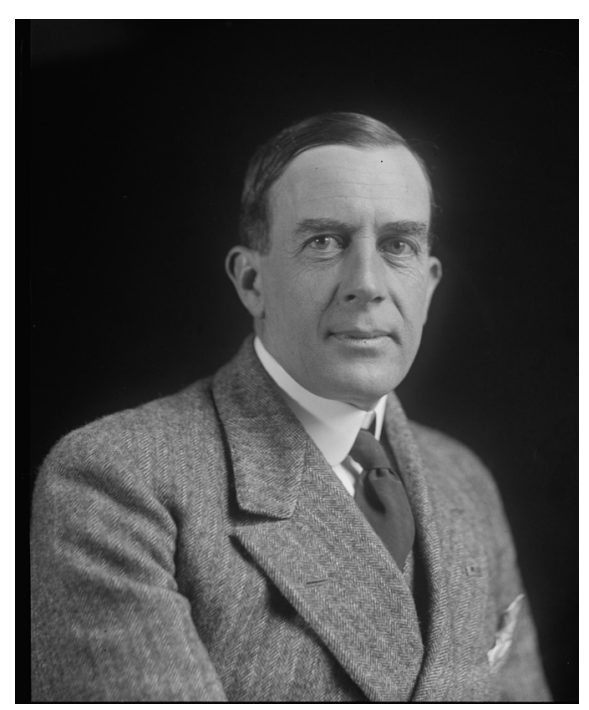

FIGURE 33. Prince Gelasio Caetani, December 12, 1922. Photograph (digital file from original). Library of Congress, Prints \& Photographs Division, LC-DIG-npcc-07583.

and image in America. The term image included not just Mussolini's general public reception, but also his very likeness. "Every time American newspapers publish a portrait of Mussolini," Caetani wrote to the Italian consuls in the United States, "they mostly rely on an awful photograph that represents him with a menacing expression and often a wild one. That gives American readers a bad impression." To address this problem, in Rome Caetani acquired a large number of photographs that in his view more faithfully and attractively presented the Duce. He then invited all the consuls to submit said photographs to the newspapers. But he prudently advised the consuls that their distribution "was not to appear as an institutional gesture, but as a special gift to a friend." Obviously, the photographs were to find their place in the newspapers' archives, ready to be used..$^{98}$

Caetani left office in 1925 following the positive public relations resolution of the Matteotti assassination: a few commentators believed that the crisis could have meant the end of Fascism but were sure it would not have meant the end of Mussolini. Comparing the Duce to Roosevelt in terms of leadership skills, Frederick Collins of Collier's rationalized this outcome as follows: "Fascism is not a world factor. Mussolini is." ${ }^{99}$ While certain sectors of the American press launched a full attack against Mussolini, ${ }^{100}$ Child's articles for the Saturday Evening Post, which began to appear a few months after he had left his Italian post on February 1924, greatly helped the Duce. ${ }^{101}$ Caetani acknowledged the former ambassador's positive impact on American public opinion toward both Mussolini and Child 
himself. ${ }^{102}$ Since they came from an independent voice, Child's counternarratives were even more effective than Caetani's efforts during the crisis. These had included an interview granted to the Associated Press and a well-publicized and reassuring meeting with President Harding. ${ }^{103}$

In both his diplomatic memoir and published essays, Child returned often to Mussolini's personal stature as a kind of Übermensch. ${ }^{104}$ By the mid-1920s, the Duce's reputation in American public culture was of someone who was more than a forceful foreign politician. To many, his unconventional approach to governance appeared to transcend Italy's borders and traditions and, as such, to produce results both exceptional and exemplary. Fascism was an experimental political system that could inspire other nations, including democratic America. For instance, anti-immigration novelist Kenneth L. Roberts viewed Mussolini's Fascism as a welcome antidote to the radical demagogy and corruption endemic to mass democracy. ${ }^{105}$ Through but also beyond his noteworthy accomplishments, Mussolini became a public personality whose entire life was worth telling and retelling to U.S. readers, particularly if writers knew how to combine exotic Italian elements with recognizably American features. As a former journalist and novelist, Child knew that. After leaving the ambassadorship, he continued to write for years about and on behalf of Mussolini. In his work, he began to weave together narratives about the Duce as both a foreign leader and an American one. His contribution paralleled other hagiographic endeavors.

\section{HAGIOGRAPHIES}

The graduating class [. . .] at Yale selected Kipling as the favorite poet. Will Rogers was the favorite world figure, with Al Capone and Mussolini tied for second honors.

CHICAGO DAILY TRIBUNE, $1931^{106}$

The key genre for the promotion of the Duce was the celebratory biography, whether in short or long format. Since the March on Rome, the American public had become used to reading short biographical profiles of the Duce. Forum, Literary Digest, and Living Age had published them as early as $1923 .{ }^{107}$ By the mid1920s, the literature on Fascism and Mussolini began to include serialized autobiographies, such as those published by the very influential United Press news agency (UP) and the popular Saturday Evening Post. Consisting of ten installments each, they bore the name of Mussolini as their sole author but actually depended on the ghostwriting of Child and other remarkable mediators. ${ }^{108}$ As we saw with Valentino, the serialized autobiography enabled promotional agents to play a very effective role, particularly when revealing previously unknown personal details about their subject's life. Overtly or covertly, Mussolini's biographers sought to position the Duce as a most likeable figure who had effortlessly adopted American 
traits, especially love of order and efficiency, but who had also maintained defining Italian ones, including authoritarian leadership. ${ }^{109}$

Child adopted this approach to Mussolinis composite character in his memoir A Diplomat Looks at Europe. Three of the memoir's eleven chapters reworked, with only minor changes, Child's SEP articles on Mussolini. ${ }^{110}$ In this volume, he unabashedly praised the Italian dictator as the architect of a new, postdemocratic nation. Child touched upon the familiar picturesque imagery of Naples before announcing the dawn of a new nation. "When I sailed up the magnificent Bay of Naples in July 1921," he wrote, "I was the American ambassador to old Italy. When, after nearly three years, I looked back at the Italian Alps on my way home, I was still the ambassador to Italy, but it was a new Italy." ${ }^{111}$ Child's account then intertwined personal and political considerations, Italy's alleged desperate need for a radical change, even a dictatorial one, and the unique fitness of Mussolini's temperament for the job:

When a people faces an intolerable situation, the real ravenous hunger is not for a program, but for a man. In modern Italy they have the tradition that when a man is really needed he will rise up from the crowd. [. . .] Benito Mussolini was the strong leader of the expression of national spirit. ${ }^{112}$

For Child, the Italian situation was not at all a foreign one. Even though Italians' recent strike-ridden history required the intervention of a strong hand, Mussolini's rise could teach something to America. In this vein, he argued:

The real story, from which Americans and our own statesmen can draw useful lessons for the future, is a story not of an armed attack upon a flabby democracy which was wheedling and coddling everyone, but a story of leadership and discipline and national unity in the labor of erecting a new government. ${ }^{113}$

The former ambassador also maintained that Fascism constituted a model antidote to the political impasse he associated with the excesses of democratic machinery, including the demands for minority rights, which in his view had led to the decline of patriotic spirit. Fascism could reverse this worldwide political and constitutional gridlock by insisting on individual responsibility and civic obligations.

Fascismo is a philosophy and an emotion running counter to the recent stream of thought, which centers mankind's attention on rights. Mussolini, without distinguishing between classes, is the first conspicuous leader since Roosevelt that has organized political unity not around rights but around duties. ${ }^{114}$

In other words, when approaching Fascism in terms of a disciplined regime, Child stressed what he considered Mussolini's exhibition of the very American (albeit traditional) traits of self-control, order, and governmental effectiveness. As a result, comparisons with American presidents were easily conceivable. "The two preeminent rulers of the world today are not difficult to name," he wrote in 1926. 
"They are Mussolini and Coolidge. Each represents in his particular power of personality the revolt of peoples against unreality and their weariness of parliamentary government-government by talk."115

In addition to Child's hagiographic work, Mussolini's American fame was also indebted to the work of a cultured Venetian woman of Jewish background, the writer and art critic Margherita Sarfatti. A publicly loyal supporter, the polyglot Sarfatti remained one of the Duce's closer advisors and nonexclusive lovers from late 1912 until the mid-1930s. She greatly influenced his theorization of the Fascist mission, particularly regarding the relationships between the Italian state and the country's artistic culture. ${ }^{116}$ Before her ghostwriting work on the serialized UP autobiography and her uncredited collaboration on what became Mussolini's My Autobiography (1928), Sarfatti wrote, under her own name, the authorized biography The Life of Benito Mussolini (1925). With a preface by Mussolini himself, published both in English and in a handwritten facsimile Italian version meant to convey authenticity, the volume appeared both in the United Kingdom and the United States with said title (preferred by the publisher) and in Italy a year later with the title Sarfatti had wanted for all editions, Dux. ${ }^{117}$ Between 1926 and 1928, the American edition went through eighteen printings (five in 1926 alone). In the same two-year period, the book was translated into eighteen languages. ${ }^{118}$

Unlike Child's political approach in his profile of the Duce, Sarfatti's booklength portrait focused more on Mussolini as a great man, specifically drawing out his character and personality as a young "Italian [. . .] par excellence." ${ }^{119}$ In describing Mussolini as an exceptional individual and a predestined leader who achieved greatness by virtue of his own willpower, Sarfatti made it clear that she refused to follow "a pedantic chronological unity." Instead, she adopted a "more genuine unity which is inherent in the character" of her hero, proceeding "as life has done with him and he with life-by leaps and bounds, by rapid advances and sudden retreats." ${ }_{120}$ Sarfatti's book intended to show how Mussolini's charismatic leadership and attractive personality, not just his politics, would appeal to the Anglo-American reader. Possibly following the lead of established biographies of the giants of the American financial and industrial world, from Andrew Carnegie to Henry Ford, she told a story that most readers must have found familiar. Mussolini was a self-made man who had managed to rise from the anonymity of the crowd, effect change in the world of politics and journalism, and modernize Italy. His remarkable character and modern personality were his weapons. He combined the very traditional trait of exceptional personal discipline with the modern traits of charming personality, determined self-improvement, and committed self-care. Unsurprisingly, a significant section of The Life of Benito Mussolini was devoted to the Duce's bodily activities and healthy diet.

Sarfatti showcased the Duce's character by summarizing his life's trajectory as a movement from humble origins to powerful positions that skillfully deployed such personal qualities as bravery and determination. In her tale, several episodes 
attested that even in his early years he had displayed the qualities of "the true leader he already was." ${ }^{121}$ Sarfatti presented the young man's uncompromising stance against his old party and in favor of Italy's intervention in the war, broadcast from the newspaper he had founded, as the mark of a true national hero and leader. Following what was already a hagiographic cliché, Sarfatti stressed how his participation in World War I and his injury were the turning points of his life. He overcame his painful near-death experience, during which he bore pain without medications, with superhuman willpower. In Sarfatti's estimate, the Italian dictator, just like Oliver Cromwell, George Washington, and Napoleon before him, had found his heroic calling during dramatic battlefield events. ${ }^{122}$ Beyond personal courage, what further launched him toward the country's modern leadership was his political vision and communicative talent.

The volume, in fact, ended with a chapter titled "Mussolini the Man" in which Sarfatti insisted on not just the strength of his personal temperament but also on his talent as a successful journalist and communicator. In passages that were reminiscent of Anne O'Hare McCormick and Ivy Lee's characterizations, Sarfatti singled out Mussolini's exceptional oratorical skills, whose "frank, sensible, brusque" methods resulted in a directness unprecedented in Italian politics. ${ }^{123}$

His eloquence, resembling the bulletins of Napoleon, is not that of a man of letters, accustomed to seek at his writing-table the nuances of expression. He is a true man of action, living through in his own experience the experiences of history and touching the heart of a people through its imagination. ${ }^{124}$

Illustrated with eleven never-before-seen photographs of the Duce (Child's volume had only two), The Life of Benito Mussolini paraded the special intimacy between author and subject. Instead of familiar poses of the Duce giving speeches or utterly still, the volume included two rarely seen photographs, one of Mussolini riding his horse and one in the company of his lioness, named Italia, which Time magazine used a year later on its second cover dedicated to the Italian leader.

The reviews of Sarfatti's account were enthusiastic. The Illustrated London News greeted it as "likely to rank with the classic biographies." It also admiringly marveled at Mussolini's preface, in which the Italian dictator did not necessarily articulate an ultimate political goal beyond his desire to "make a mark on [his] era with [his] will, like a lion with the claws." The British paper found the way Mussolini described himself vis-à-vis his fame astonishing. Rather than defining himself as a political visionary, his self-assessment focused on his transformation under the media spotlight. The dramatic expansion of Mussolini's public self through an intense and incessant degree of interest had produced a sort of anthropological change in his persona that went far beyond political merits and goals. Mussolini wrote:

The public man is born "public." [. . .] The public man, like the poet, is born to his doom. He can never escape it. [. . . I am perfectly resigned to my lot as a public 
man. In fact, I am enthusiastic about it. Not just on account of my publicity which it entails. [. . .] No, it is the thought, the realization, that I no longer belong merely to myself, that I belong to all-loved by all, hated by all —-that I am an essential element in the lives of theirs: this feeling has on me a kind of intoxicating effect. ${ }^{125}$

Quite similarly, in his review of the Italian dictator's first authorized biography, John Carter of the New York Times wrote that "its principal interest lies in the currency it gives to the Mussolinic Legend." In other words, the degree of public interest-his celebrity quota, so to speak-was for the reviewers the true and only criterion on which to assess him politically. "Sarfatti's book," Carter added, "is important for making us realize that it is impossible to appraise a statesman on any other basis than mythopoeia." ${ }^{126}$ Carter attributed the Duce's proud leadership to his Latin masculinity by sexualizing his relationship with Italians and with Italy as a whole:

Latin races appreciate virility in a statesman far more than do the Anglo-Saxon, whose politicians are expected to have distinguished themselves by their conspicuous chastity at least before seeking office. Mussolini's grasp on Italy is susceptible to the analysis of the psychology of sex. ${ }^{127}$

Possibly because written by someone who many knew to have been, and who perhaps still was, intimate with the Duce, Sarfatti's The Life of Benito Mussolini appeared to reviewers open to consideration about the Duce's virility. At the same time, however, Sarfatti's work also represented a very modern way to read the personal dimension of political leaders. The virtues of public men-as the Venetian author implied and as her reviewers recognized-could not be limited to questions of morality, policy, and political talent but had to include insights into a person's physical traits and inclinations.

In the following years, Sarfatti continued to weave biographical narratives about the Duce, but this time not under her own name. She apparently contributed to two serialized biographies of Mussolini, published by the UP news agency and the Saturday Evening Post. They exhibited her daring stylistic approach but were also in tune with the modern American notion of personality as "mastery and development of the self," which entailed an explicit discussion of bodily talents and dispositions. These biographies focused on such celebrated and uplifting traits as work efficiency but also gave large space in praise of Mussolini's magnetic voice, rhetorical ability, and physical self-care. The first of these serialized biographies, entitled Mussolini's Own Story of His Busy Life, was syndicated between January 5 and January 15, 1927, by UP, which at the time served over a thousand newspapers across the United States and in another thirty-five countries. ${ }^{128}$ Apparently, the authors of this series were Sarfatti and UP's Rome manager, Thomas B. Morgan. ${ }^{129}$ In "one of the outstanding newspaper exploits of recent years," boasted the promotional material as if it were referring to a film celebrity, "Mussolini tells the intimate, personal story of his daily life." ${ }^{130}$ 
Over ten articles, the series deploys the theme of efficiency to an exceptional degree, as its title's use of the word busy foreshadows. In the introduction to the first article, the editor presents the dictator as someone who "works intensively fourteen to sixteen hours a day" and who regards "personal efficiency [as] his fetish" to the point that "every minute of each day is scheduled in advance." ${ }^{131}$ Mussolini's opening words read like a Macfadden self-help manual of personal productivity: "It has been my rule of life to employ the body and mind to render the maximum output." To guarantee such efficiency, Mussolini notes, he has to follow a series of strict rules and personal daily routines, including eating and drinking habits (i.e., milk instead of alcohol). ${ }^{132}$ The link between control of his own body and that of his country was an obvious rhetorical isomorphism linking body politics with body economics. It also held a proud nationalist dimension. By transferring the concept of efficiency from American business culture to himself and his own administration, Mussolini sought to contrast the stigmatizing characteristics usually attributed to Italians - such as disorganization, ineptitude, and sentimentalism - with the image of a new Italian man who was efficient, pragmatic, and, most importantly, disciplined. ${ }^{133}$ At the same time, he acknowledges the American imprint of the vaunted notion of work efficiency. "The United States [...] created smooth-running organizations of human units," he writes in the fourth article of the series. "It is just such business efficiency on a larger scale we have tried to work into the government machine of Italy. We are succeeding." 134 Ultimately, Mussolini's work efficiency was associated with his effort to change, renew, and improve Italy and the Italians effectively, but it was also well attuned to the businesslike American attitude that emphasized achieving results no matter the personal costs.

Shortly after, another series much richer in tone and content appeared in the Saturday Evening Post. Published from May 5 to October 27, 1928, in one of America's most popular periodicals, this series did not have single, overarching title and was later republished in a volume under the title of My Autobiography. ${ }^{135}$ Allegedly written by Mussolini himself, both the SEP installments and the resulting volume in fact had multiple authors. Mussolini's brother Arnaldo, possibly with Sarfatti, wrote the Italian text. Child translated this into English in collaboration with the Corriere della Sera correspondent Luigi Barzini Jr. ${ }^{136}$ Child also wrote the volume's eight-page foreword, finalizing it probably during a late 1927 trip to Rome. ${ }^{137}$

In the foreword, Child described Mussolini's political leadership as "celebrity" and adopted a cinematic term of comparison ("his own size on the screen of history") to emphasize the modernity of his public image.As in other accounts, Mussolini emerges in My Autobiography as a leader who was born in a great nation but personally came from nothing. Even though he had a strong father figure, in his early life he was often aimless. The Great War marked his path and made him see the "the death struggle of a worn-out democracy," to quote one of the chapters, found Fascism, and take Rome. The book also includes chapters on the "five years of government," the future of the Fascist state, and the 
"political and social doctrine of fascism." But Child's foreword provides the lens with which all the narrative can profitably be read as the profile of a larger-thanlife politician.

The virilized physical newness of Mussolini's energetic political leadership, visible to Child in the dictator's "firm jaws" or audible in "a sentence suddenly ejaculated," glorified rather than tamed any reference to the dictatorial nature of his regime. ${ }^{138}$ In an American context that could safely imagine from afar what it would be like to witness the demise of democratic institutions, Child did not see any reason to downplay the autocratic measures that Fascist government had taken:

In our time it may be shrewdly forecast that no man will exhibit dimensions of permanent greatness equal to those of Mussolini. [. . . It is one thing to administer a state. The one who does this well is called statesman. It is quite another thing to make a state. Mussolini has made a state. That is superstatemanship. ${ }^{139}$

As he did in his IAS speech and elsewhere, in the foreword Child transitions from an emphasis on Mussolini's domestic political leadership, which had resulted in an infusion of vigor into Italy's new generations ("youth itself, appears as if born with a new spirit, a new virility bred in the bones"), to comparisons with his political idol. "Mussolini, like Roosevelt," he notes, "gives the impression of an energy which cannot be bottled, which bubbles up and over like an eternally effervescent, irrepressible fluid." ${ }^{140}$

My Autobiography, like other biographical profiles of the Duce, also seeks to stress the extent to which Mussolinis Latin masculinity made him quite different from his American counterparts. While describing his work discipline and political aspirations, for instance, Mussolini often advised against the presence of women in the workplace. "I have given imperative orders that [... ] where I work [. . .] no woman shall be admitted," he noted in an installment of the UP autobiographical series, since women "interfere with the efficient procedure of the work." ${ }^{141} \mathrm{He}$ did not hesitate repeating such misogynist and backward views on other occasions, even when a woman was interviewing him. Still, his prejudice did not prevent women journalists from expressing admiration for his charming Latin personality - a contradictory phenomenon that paralleled Valentino's potentially damaging, but regularly forgiven, public statements against gender equality.

\section{“MUSSOLINI A SHEIK”}

I began all over again to meditate upon this extraordinary man whose attitude toward women is so disdainful and yet who has so undeniable a charm. Psychoanalysis cast aside, I found myself reflecting before the Chigi Palace entrance was reached: "No wonder women are crazy about him."

ALICE ROHE, LIBERTY MAGAZINE, $1927^{142}$ 
In different ways, Child and Lamont emphasized Mussolini's leadership and political ingeniousness as well as the regime's suitability to the Italian people. A few American female journalists stressed the same political angle in their reports. Yet the mere fact of their gender seems to have pushed them, either by their own will or by the insistence of their editors, to combine political analysis with insights into Mussolini's personal temperament. ${ }^{143}$ If the emphasis on leadership constituted the shared political domain between the Divo and the Duce, personal charisma and Latin sensuality provided the erotic one. A few women writers performed this double public relations service. In addition to the already mentioned Anne O'Hare McCormick, we should also include UP writer and photojournalist Alice Rohe, who translated the Fascist regime's political novelty into a masculine model and for more than ten years penned a positive account of the chauvinist Mussolini.

As already discussed, the Great War was a seismic event for communication and journalism. More female reporters than ever before joined male colleagues on European soil to cover the war. Kansas-born Alice Rohe was one of them. A few jobs as a reporter for newspapers in Kansas and Colorado enabled her to cross paths with George Creel. After she joined the CPI, she soon became a national figure. ${ }^{144}$ Already in Rome in 1914 as a correspondent for UP and the Exchange Telegraph of London, she remained in the Italian capital until 1919. By then she had become the first woman to manage the Rome office of UP's international bureau. ${ }^{145}$

A few days after the March on Rome, Rohe interviewed Mussolini for the New York Times. At the end of the long, four-column piece, after offering praise for his youth, outstanding culture, and visionary leadership talent, Rohe focused on what today we might refer to as his gender politics. A committed defender of women's equal rights, Rohe asked Mussolini whether he thought that "the mind of a woman, given the same opportunity for development, the same education, doesn't function as well as that of a man." "Certainly not-it is impossible," he replied. ${ }^{146}$ Rohe voiced her disappointment at the Duce's unapologetic display of male chauvinism but was not wholly discouraged. She gently reprimanded him, but closed the piece with a surprisingly affectionate tone: Mussolini "laughed good-naturedly, but with that fine superiority with which the Latin male regards woman." ${ }^{147}$ An article Rohe published five years later in Liberty Magazine on the Duce as "idol of women" best captured this contradictory reaction in its subtitle- "He Pours Contempt on the Softer Sex-And It Adores Him!" (figure 34). ${ }^{148}$

That article begins by reporting how the women of Rome, "titled beauties of ancient Italian lineage, look upon the Fascist Dictator." ${ }^{149}$ They adore what he has done for Italy, but most surprisingly they adore him. Rohe describes one of them as behaving "like a schoolgirl over her favorite movie hero." By her own admission, the comparison with the film world led her to a recently published article in the search for a successor to Valentino in Italy. Rohe then combines the two domains, film and political stardom, in a way that surprises even her: 


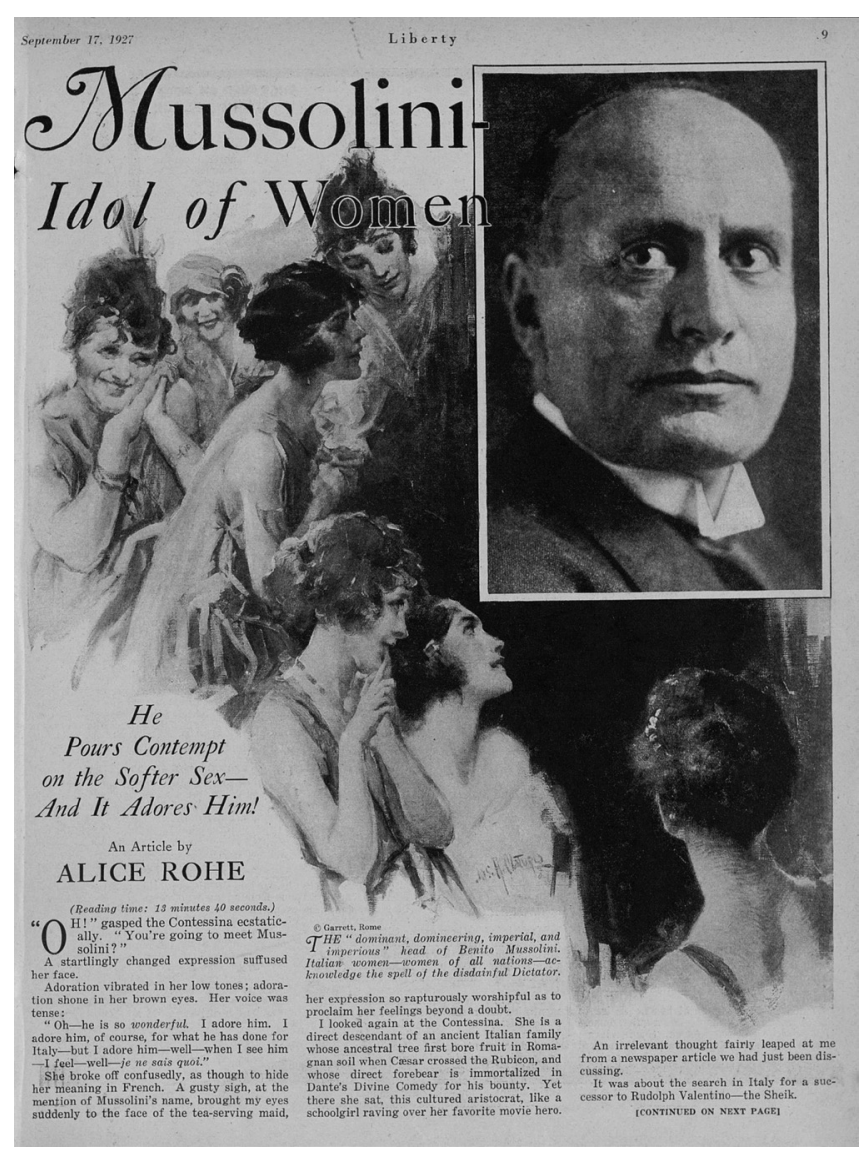

FIGURE 34. Mussolini's perplexing appeal. Alice Rohe, "Mussolini: Idol of Women," Liberty Magazine, September 17, 1927, 9.

Suddenly I began to think of Mussolini in a new light. Why search further? I struggled to suppress the boldly intrusive idea. Mussolini a sheik-perish the thought! Yet this dominant, indomitable Dictator, whose contempt for women is proverbial, not only has Italy in the hollow of his hand, but he has Italy's women at his feet. ${ }^{150}$

The equation of the real Mussolini with a Hollywood archetype require articulation: on what grounds is it based? The author's visits to Mussolini's rallies reveal to her the outstanding appeal he enjoyed among Italian women, to the point that she herself does not feel immune from it. "Everywhere adoration illuminated the faces of the women," she observes. "Young and old, they kept creeping nearer and nearer to where he was speaking. Before I realized it, I, too, was among them, drawn forward by the magnetism of the black-shirted premier." While the general enthusiasm of the masses for the Duce may find an explanation in a broad discussion 
about leaders' power over mobs and masses ("To see Mussolini before his cohorts is to understand the power of the individual over the mass mind"), for Rohe, there is something else worth exploring. Given the Duce's public disdain for any role for women beyond biological service to the nation, Rohe wonders how to explain "this feminine phenomenon" and whether it proves "conclusively that women prefer the dominant, patronizing, arrogantly indifferent male." At first, Rohe attributes such a self-defeating attitude to an Italian cultural trait. "Italian women worship a dominant male. They revel in submission to super contempt," she charges, and she identifies such misplaced "feminine idolatry" for a man who mainly regards women as servants as evidence of "a somewhat primal force in modern, Fascist Italy." And yet, she notices, "I have seen too many of my own countrywomen completely enthralled [by him]." They are a diverse lot: "sophisticated cosmopolites, 'hard-boiled flappers', placid wives of prominent U.S. citizens, skeptical newspaper women, 10o-percent feminists." But no matter their backgrounds, when they have the chance to meet "Italy's man of destiny," they reemerge "as utter vassals."151

How could Rohe explain women's tolerance for the Duce's misogynist attitude, which had not changed over the years? To her dismay, the explanation lies in their experience of his irresistible personal appeal, a "great magnetism" which she herself has experienced. In a combination of psychoanalytic reading and cinematic reviewing, Rohe states, "The plain answer is sex appeal," and "Dr. Freud could give the most illuminating explanation [by suggesting that] this element is at all times extremely vital in Italy" ${ }^{152}$ Rather than describing sex appeal as resulting from a direct relationship between the Duce and his admirers, her exploration of this cinematic quality leads her identify a photographic mediation that is close to her reporting practice: the close-up view. "The very strength of the face, with its uncompromising, sensual mouth, the compelling domination of the prominent eyes, the brutal tenacity of the head", she admits, "radiated sex appeal" because a photographic camera captured it at close range before countless reproductions multiplied it ad infinitum. "When you study a personal close-up of this dominant, domineering, imperial, and imperious face, the spell which he exerts over women is not surprising." 153 Ultimately, his mass-reproduced captivating charm easily lends itself to comparisons with stars' appeal. A few months earlier Elinor Glyn had even included Mussolini (and the Prince of Wales) among those who "have IT." 154

Rohe did not change her view or tone over the years. In 1937 she could still write: "There are certain types of women who are even attracted by his contempt." 155 This time she provides a fresh insight: "I have known Mussolini for fifteen years. I have watched his power over the mass mind, but more significant because of the publicity given him in the Great Lover role, I have witnessed his power over women." ${ }_{156}$ It was not just "that he has 'It' and 'Sex Appeal.' " More cogently, it was the fact that something of the private dimension of this Italian political leader had been made to become his defining trait. 
The sudden introduction of the love element into the macabre drama which Mussolini is enacting on the world stage calls attention to an important phase of Il Duce's life. This is his power over women, a power which has played no small part in his success. ${ }^{157}$

The public exposure of a person's private personality, unprecedented for someone playing such a demiurgic political role, was for Rohe part and parcel of his cinematic allure. A few articles that appeared in Liberty Magazine were even more explicit with cinematic metaphors and terms of comparison. In a spring 1927 piece on screen tests, the method of determining actors' cinematic suitability and appeal beyond mere physical appearance, the staff writer and editor Brenda Ueland points out that passing a screen test is just a first step toward success. "To become a star you must have something else. Some call it 'charm;' some 'personality;' some, 'sex appeal." 'She inevitably quotes Elinor Glyn, "who calls it 'it." The rest of the article constitutes a series of insights on the subject shared by a Hollywood filmmaker, A. Edward "Eddie" Sutherland. After referring to famous actors, Sutherland argues that history's greatest statesmen had cinematic magnetism:

When Napoleon walked toward a squad of men whose rifles were pointed at him, they couldn't fire. [.. . ] Now, Napoleon and Caesar, if they had gone into the movies, would have become great stars. So would Mussolini, Bernard Shaw, Nell Gwyn, Henry IV, Abélard and Héloïse, Lord Nelson, Diane de Poitiers, and many others. And that is about the best way I can explain it. ${ }^{158}$

The ease with which the Hollywood director moved from discussing stars' successful screen tests to the charm of great statesmen impinges upon two intersecting domains. Film culture does not just pertain to leisure time; political leadership does not just pertain to policy positions, ideological convictions, or (traditional) personal character. True, political adversaries deployed a combination of alarm and sarcasm in their emphasis on Mussolini's performative talent. Anti-Fascist historian Gaetano Salvemini labeled him a "clown," while expatriate anarchist Camillo Bernieri went so far in 1934 as to call the Duce "the Rodolfo Valentino of politics." "159 But the intersection of the two domains produced comparisons between the Divo and the Duce, in a speech or a cartoon, that were not motivated solely by political antagonism. In an interview, the Hollywood actress Nita Naldi, who had played the femme fatale in Valentino's Blood and Sand (1923) and was a close friend of the actor, confessed her preferred type of male companion. "I like very dark handsome men with slick hair who wear evening clothes like ambassadors," Naldi confessed to the reporter that she liked men who look like Rudolph Valentino. But she went on: "Also I like them to be fierce and quarrelsome. Soldiers I adore! Mussolini! Cave men!"160 In her terms, "Valentino" was a person, whereas "Mussolini" was an attribute, a popular, and thus mass-mediated, type of masculinity that was "fierce and quarrelsome" - and as such akin to a "sheik." For the Duce's masculinity to become "typical," it had to be publicly associated with 
the personal style of his political governance rather than with its substance. And it could achieve this level of cultural amplification mainly through references to motion pictures. Cinema, in fact, provided the terrain of comparison as well as of competition with Valentino.

An illustration that appeared in the January 1926 Liberty Magazine captures exactly that (figure 35). ${ }^{161}$ Created by the famous New Yorker cartoonist Ralph Barton, the drawing pairs the Divo and the Duce under the fresh, personalized terms of a public confrontation that obviously stresses both their differences and similarities. ${ }^{162}$ Graphically, the two figures are in parallel positions, with the back and top of their heads radiating the same white reflections out of well-oiled hair or a formal hat (or topper) ${ }^{163}$ Calvino would have recognized in the image the "first Mussolini," the emblem of respectability and restored order who at official ceremonies habitually sported a morning coat and a tie. ${ }^{164}$ The cartoon's implied context is Valentino and Mussolini's widely publicized rift over the former's decision to acquire U.S. citizenship and the latter's response of having his films banned in Italy. In the drawing, however, the actual terrain of their confrontation is not legal citizenship but cinematic visibility. Underneath the cartoon is a long caption that begins in capital letters. It goes on to explain the drawing in terms that certainly refer to the issue of citizenship but qualify the two figures in cinematic terms:

Benito Mussolini, Italy's Premier and leading news-reel actor, caught off his guard by our camera man as he views a poster announcing Rudolph Valentino in a motion picture. A boycott was shortly afterwards proclaimed on Valentino pictures. ${ }^{165}$

The cartoon's raison dêtre (and its design) was the fact that Mussolini and Valentino were both public popular figures, subjects of countless publicity initiatives. While in the mid-1920s this may have appeared obvious for a film star, it was still a novelty for a politician. In a 1928 NYT article, UP publicity director Warren Nolan, who had handled publicity for Chaplin, Pickford, Fairbanks, and even for Valentino's funeral, praised Mussolini as a masterful "space-grabber."

Benito Mussolini is the world's champion space-getter, because in five years he has press-agented Italy into a front-line position as a world power and himself into Julius Caesar's mighty sandals. Il Duce is even more famous than that countryman of his, Rudolph Valentino, whose illness and death sent more verbiage over press wires than did the illness and death of an ex-president. ${ }^{166}$

Further, the basis for the cartoon's comparison between Valentino and Mussolini was the fact that they were both film stars-one of fiction films, the other of newsreels. The recognition that Mussolini, too, was a film celebrity had been made explicit and literal by the news and by the release of films starring the Italian leader. These began with The Eternal City (1924) and continued with The Man of the Hour (1927) and several hard-to-find American newsreels, as we shall see in the next chapter. ${ }^{167}$ Yet, as we saw at the beginning of this chapter, the identification 


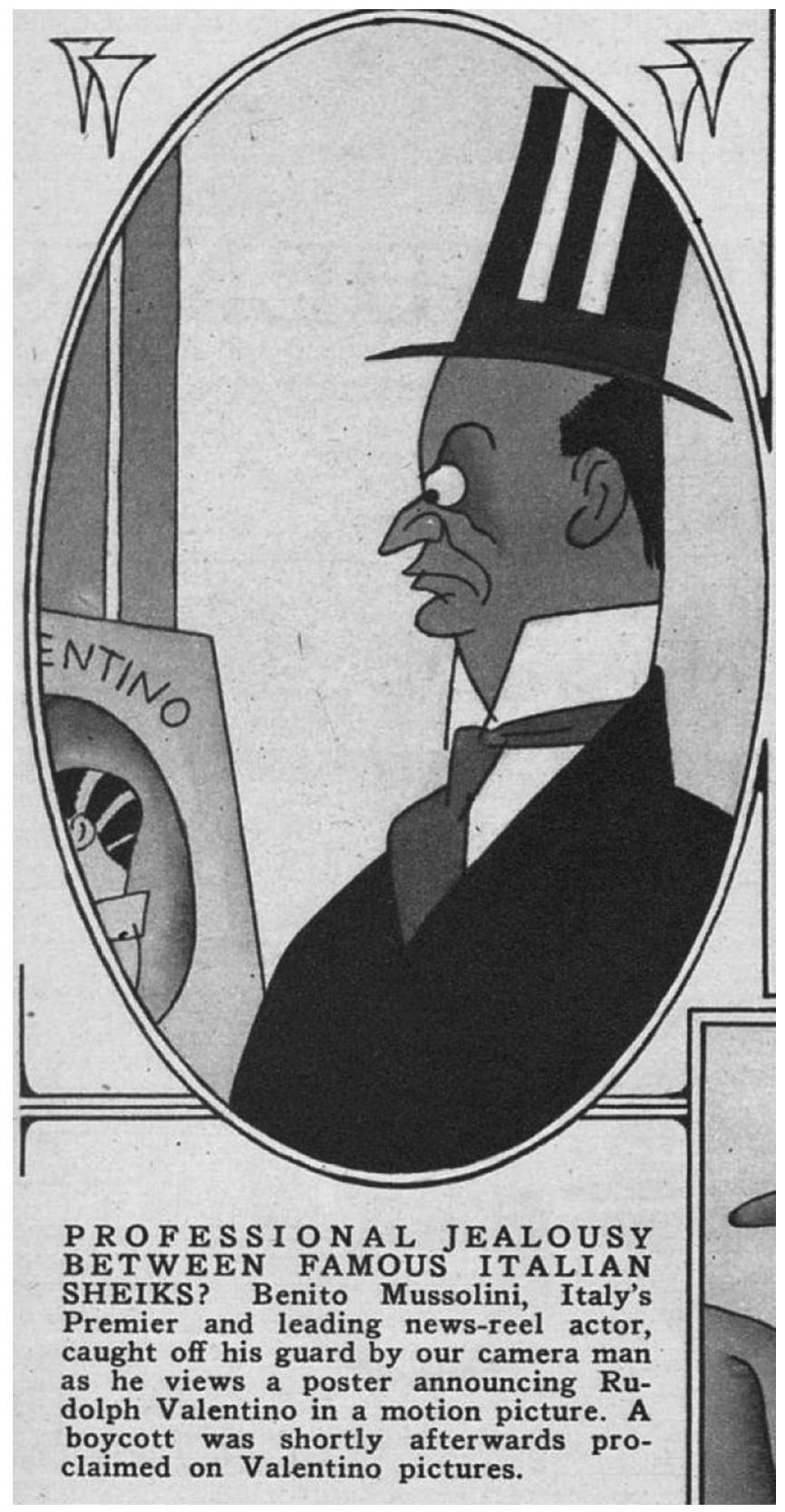

FIGURE 35. Mussolini versus Valentino. Ralph Barton, "News of the World," Liberty Magazine, January 16, 1926, 53. 
of Mussolini as "movie star" had inaugurated his popular hagiography in early November 1922, when no films about him were known to be in the making. ${ }^{168}$ The fact that Mussolini was considered "cinematic" in American press discourse before being screened in the New World supports the methodological postulate of this work that the cinema effect extended beyond the domain of movie theaters. ${ }^{169}$ It is time now to look closely at how American and Italian films exhibited in the United States sought to tell stories about Mussolini as Fascist leader by showcasing his role as political leader through romanticized transfigurations. 